\title{
Modified Starch-Chitosan Edible Films: Physicochemical and Mechanical Characterization
}

\author{
Monserrat Escamilla-García ${ }^{1}$ (D), Andrea Reyes-Basurto ${ }^{1}$, Blanca E. García-Almendárez ${ }^{1}$, \\ Elvia Hernández-Hernández ${ }^{1}$, Georgina Calderón-Domínguez ${ }^{2}$, Giovanna Rossi-Márquez ${ }^{3}$ \\ and Carlos Regalado-González ${ }^{1, *}$ (i)
}

1 Facultad de Química, Departamento de Investigación y Posgrado en Alimentos, Universidad Autónoma de Querétaro, C.U., Cerro de las Campanas S/N, Col. Las Campanas, Querétaro 76010, Mexico; moneg14@hotmail.com (M.E.-G.); andy108rb@hotmail.com (A.R.-B.); blancag31@gmail.com (B.E.G.-A.); elviahdez2@prodigy.net.mx (E.H.-H.)

2 Departamento de Ingeniería Bioquímica, Instituto Politécnico Nacional, Av. Wilfrido Massieu Esq. Cda. Miguel Stampa S/N, Gustavo A. Madero, Ciudad de Mexico 07738, Mexico; ginacaldero@hotmail.com

3 Instituto Tecnológico “José Mario Molina Pasquel Henríquez", Unidad Académica Lagos de Moreno, Libramiento Tecnológico No. 5000, Col. Potugalejo de los Romanes, Lagos de Moreno C.P. 47480, Mexico; gio_rossi@yahoo.com

* Correspondence: regcarlos@gmail.com; Tel.: +52-442-123-8332

Academic Editor: Isabel Coelhoso

Received: 27 October 2017; Accepted: 2 December 2017; Published: 7 December 2017

\begin{abstract}
Starch and chitosan are widely used for preparation of edible films that are of great interest in food preservation. This work was aimed to analyze the relationship between structural and physical properties of edible films based on a mixture of chitosan and modified starches. In addition, films were tested for antimicrobial activity against Listeria innocua. Films were prepared by the casting method using chitosan (CT), waxy (WS), oxidized (OS) and acetylated (AS) corn starches and their mixtures. The CT-starches films showed improved barrier and mechanical properties as compared with those made from individual components, CT-OS film presented the lowest thickness $(74 \pm 7 \mu \mathrm{m})$, water content $(11.53 \% \pm 0.85 \%, w / w)$, solubility $(26.77 \% \pm 1.40 \%, w / v)$ and water vapor permeability $\left((1.18 \pm 0.48) \times 10^{-9} \mathrm{~g} \cdot \mathrm{s}^{-1} \cdot \mathrm{m}^{-1} \cdot \mathrm{Pa}^{-1}\right)$. This film showed low hardness $(2.30 \pm 0.19 \mathrm{MPa})$, low surface roughness $\left(R_{\mathrm{q}}=3.20 \pm 0.41 \mathrm{~nm}\right)$ and was the most elastic (Young's modulus $=0.11 \pm 0.06 \mathrm{GPa}$ ). In addition, films made from CT-starches mixtures reduced CT antimicrobial activity against L. innocua, depending on the type of modified starch. This was attributed to interactions between acetyl groups of AS with the carbonyl and amino groups of $\mathrm{CT}$, leaving $\mathrm{CT}$ with less positive charge. Interaction of the pyranose ring of $\mathrm{OS}$ with $\mathrm{CT}$ led to increased $\mathrm{OH}$ groups that upon interaction with amino groups, decreased the positive charge of $\mathrm{CT}$, and this effect is responsible for the reduced antimicrobial activity. It was found that the type of starch modification influenced interactions with chitosan, leading to different films properties.
\end{abstract}

Keywords: edible films; chitosan; modified starch; Raman spectroscopy

\section{Introduction}

The development of plastic food packaging has allowed shelf life extension of food products; however, overuse of synthetic materials has led to serious environmental problems. Thus, there is increased interest of food and packaging industries to develop alternative solutions, such as the study of edible films [1]. The functionality of films based on starch depends on the ratio of amylose to amylopectin. High amylose content produces elastic films whereas high amylopectin starch leads to films exhibiting poor mechanical properties [2]. Chemical modifications of starch including acetylation 
and oxidation may be used to improve edible films properties. Carbonyl and carboxyl groups of oxidized starch (OS) enhance hydrogen bonds among adjacent amylopectin molecules resulting in a more efficient association process [3]. On the other hand, waxy starch (WS) may be used as film forming material because of lower extent of retrogradation when compared to amylose [4].

Chitosan (CT) is a linear polysaccharide obtained by deacetylation of chitin, which comprises $\beta$-(1-4)-2-acetamido-D-glucose and $\beta$-(1-4)-2-amino-D-glucose, CT has many potential applications in the food industry because of its unique functional, nutritional and physicochemical properties besides, it enjoys the "generally recognized as safe" (GRAS) status. CT has been used for food coatings, as food additive due to its excellent emulsifying properties and source of dietary fiber [5]. It has been used to obtain elastic and transparent films, in addition to exerting antimicrobial activity [6]. CT antimicrobial activity is influenced by $\mathrm{pH}$, molecular weight, degree of deacetylation, distribution of the deacetylated groups along the chain, ionic strength of the medium and the associated counterion in its salt [7]. CT films show low oxygen permeability and moisture content but high-water vapor permeability (WVP) [8]. The effect of CT on edible films made from mixtures with different types of starch and the relationship among structural and chemical interactions and physical properties have not been studied. The aim of this work was to analyze the effect of CT on physicochemical and structural properties of edible films based on WS, oxidized and acetylated starches.

\section{Materials and Methods}

\subsection{Materials}

Medium molecular weight chitosan from shrimp shells ( $375 \mathrm{kDa}$, deacetylation $\geq 75 \%$ ), glycerol ( $\geq 99.5 \%)$, Tween 80 and hydroxylamine hydrochloride (99\%) were purchased from Sigma-Aldrich (St. Louis, MO, USA), lactic acid (85\%) was obtained from Fermont (León, Mexico). Oxidized, acetylated and waxy starches were supplied by Ingredion (San Juan del Río, Mexico).

\subsection{Methods}

\subsubsection{Starch Characterization}

\section{Acetyl Content}

Acetylation was determined following Sánchez-Rivera et al. [9]. Acetyl percentage (w/w) was calculated using Equation (1), whereas degree of substitution (DS) was calculated using Equation (2).

$$
\begin{gathered}
\% \text { Acetyl }=\frac{\left[\left(V_{\mathrm{HCl}}-V_{\mathrm{HCl} \mathrm{b}}\right) \times M_{\mathrm{HCl}} \times 0.043 \times 100\right]}{m} \\
\mathrm{DS}=\frac{(162 \times \text { Acetyl }(\%))}{[4300-(42 \times \text { Acetyl }(\%))]}
\end{gathered}
$$

where $V_{\mathrm{HCl}}$ and $V_{\mathrm{HCl}}$ are the volumes of $0.5 \mathrm{M} \mathrm{HCl}$ used for sample and blank titrations respectively, $m$ is sample weight $(\mathrm{g}), 0.043$ is the meq of acetyl group, 4300 is the acetyl molecular weight times 100, whereas 162 is the molecular weight of anhydrous glucose in the starch molecule.

\section{Oxidized Starch}

Carboxyl and carbonyl content were evaluated according to Zhou et al. [10]. Carboxyl content $(\% w / w)$ was obtained using Equation (3).

$$
\% \mathrm{COOH}=\frac{\left[V_{\mathrm{NaOH}}-V_{\mathrm{NaOH} \mathrm{b}}\right] \times M_{\mathrm{NaOH}} \times 45 \times 100}{m}
$$

where 45 is the molecular weight of carboxyl group, $M$ is the molarity of $\mathrm{NaOH} ; V_{\mathrm{NaOH}}, V_{\mathrm{NaOH}}$ are the volumes of $0.05 \mathrm{M} \mathrm{NaOH}$ used for sample and blank titrations, respectively. 
Carbonyl content $(\% w / v)$ was determined following the Sandhu et al. [11] method and was obtained from Equation (4).

$$
\% \text { Carbonyl }=\frac{\left[V_{\mathrm{HCl} \mathrm{b}}-V_{\mathrm{HCl}}\right] \times N_{\mathrm{HCl}} \times 0.028 \times 100}{m}
$$

where $V_{\mathrm{HCl}}$ and $V_{\mathrm{HCl}}$ are the volumes of $0.1 \mathrm{M} \mathrm{HCl}$ used for blank and sample titration respectively, $\mathrm{N}_{\mathrm{HCl}}$ is the normality of $\mathrm{HCl}$ and 0.028 is the meq of carbonyl group.

Amylose and Amylopectin Determination

The amylose/amylopectin content of the starch samples used was determined using the amylose/amylopectin kit (Megazyme, Wicklow, Ireland). Amylose $(\% w / w)$ was directly calculated following supplier instructions [12].

\subsubsection{Chitosan Edible Film Formation}

A suspension of chitosan $(1 \% w / v)$ in lactic acid $(0.5 \% v / v)$ was stirred for $60 \mathrm{~min}$ at $80{ }^{\circ} \mathrm{C}$, then glycerol was added at 1:1 $(w / w)$ ratio, followed by Tween $80(0.2 \% w / v)$ and the mixture was stirred for $10 \mathrm{~min}$ at room temperature. Films were formed by the casting method and dried at $60{ }^{\circ} \mathrm{C}$ and $50 \%$ relative humidity (RH) in an environmental chamber (Binder, KBF 115, Tuttlingen, Germany), for $24 \mathrm{~h}$ [13].

\subsubsection{Starch Edible Film}

Three different starch suspensions (oxidized, acetylated and waxy) were prepared. Suspensions at $3.5 \%(w / v)$ in distilled water were stirred at $90{ }^{\circ} \mathrm{C}$ for $30 \mathrm{~min}$, added with $1 \%(w / w)$ glycerol [14]. Casting and films drying were conducted as in Section 2.2.2.

\subsubsection{Chitosan-Starch Edible Films}

Three different starch suspensions (OS, AS, WS) were prepared as in Section 2.2.3, whereas a CT suspension was prepared as in Section 2.2.2. Mixtures of chitosan with each of the three starches were prepared, comprising a 3:1 $(w / w)$ starch: chitosan ratio and stirred for $5 \mathrm{~min}$ at room temperature. Films were obtained by the casting method as in Section 2.2.2. To obtain similar thicknesses, the same volume of suspension $(20 \mathrm{~mL})$ was used to produce all films.

\subsubsection{Physical Characterization}

Films thickness, color, WVP, solubility and roughness were determined. Film thickness was measured using a digital micrometer (Mitutoyo, 293-185, Kawasaki, Japan), whereas color was evaluated according to the CIELAB method [15], using the parameters $L^{*}=$ lightness, $\pm a^{*}=$ green to red color component and $\pm b^{*}=$ blue to yellow color component. A Minolta CR400 colorimeter (Minolta, Osaka, Japan) was used, with illumination source D65 and $10^{\circ}$ angle, color was standardized using a white reference plate. Color differences were calculated using Equation (5).

$$
\Delta E=\sqrt{\Delta a^{2}+\Delta b^{2}+\Delta L^{2}}
$$

where $\Delta E$ is the color difference, $\Delta L$ is brightness difference; $\Delta a$ is the red-green chromaticity difference and $\Delta b$ is the yellow-blue chromaticity difference [16].

The gravimetric method ASTM E 96-80 [17], was employed to calculate WVP, using permeability cells of $3.2 \mathrm{~cm}$ in diameter. A saturated solution of $\mathrm{KNO}_{3}\left(92.5 \% \mathrm{RH}, \mathrm{T}=25^{\circ} \mathrm{C}\right)$ was added into the cells and films circles of $4 \mathrm{~cm}$ in diameter placed on top of them. Permeability cells were placed in a desiccator containing a saturated $\mathrm{NaCl}$ solution $\left(75 \% \mathrm{RH}, \mathrm{T}=25^{\circ} \mathrm{C}\right)$ and weight variations were recorded until constant weight. WVP was obtained from Equation (6) [18]. 


$$
\mathrm{WVP}=\frac{\Delta W}{t A} \times \frac{L}{\Delta P}
$$

where $\Delta W$ is the change in weight of the permeation cell $(\mathrm{g}), t$ is the duration of the test $(\mathrm{s}), A$ is the contact area of the edible film $\left(\mathrm{m}^{2}\right), L$ is the thickness of the film $(\mathrm{m})$ and $\Delta P$ is the pressure difference (Pa).

Films were cut into squares of $2 \mathrm{~cm}$, placed in petri dishes, dried at $103 \pm 2{ }^{\circ} \mathrm{C}$ for $24 \mathrm{~h}$ and weighed, followed by immersion in $15 \mathrm{~mL}$ of distilled water for $6 \mathrm{~h}$ with constant agitation on a rocker plate (Ultra Rocker, Bio Rad, Carlsbad, CA, USA). Then, samples were passed through Whatman No. 1 filter paper (Whatman, Maidstone, UK) and the remaining pieces of film were recovered, dried for $24 \mathrm{~h}$ at $103 \pm 2{ }^{\circ} \mathrm{C}$ and the final dry weight was determined. Solubility $(\% w / w)$ was obtained using Equation (7) [19].

$$
\% \text { Solubility }=\frac{\text { initial weight }- \text { final weight }}{\text { initial weight }} \times 100
$$

The edible films surface roughness was evaluated using atomic force microscopy (AFM) (di Multimode V, Veeco, Plainview, NY, USA). This method produces a 3D profile of the sample surface by measuring changes in force between a cantilever and the sample [20]. Roughness was calculated from the images of the edible film surface, calculating the square root of the deviation from a mean plane of the surface peaks and valleys $\left(R_{\mathrm{q}}\right)$ (Equation (8)). The average of the absolute values of the surface height deviations measured from the mean plane $\left(R_{\mathrm{a}}\right)$, was calculated using Equation (9), from the Nano Scope Analysis 1.2 software (Veeco, Plainview, NY, USA). The method of contact and using silicon tips (Bruker RTESP Cantilever, Karlsruhe, Germany) was applied with a resonant frequency of $286-362 \mathrm{kHz}$ and a spring constant of $20-80 \mathrm{~N} / \mathrm{m}$ and a scan speed of $1 \mathrm{~Hz}$ with a resolution of $256 \times 256$ pixels.

$$
\begin{aligned}
& R_{\mathrm{q}}=\sqrt{\frac{\sum Z i^{2}}{N}} \\
& R_{\mathrm{a}}=\frac{1}{N} \sum_{j=1}^{N} \mathrm{Z}_{j}
\end{aligned}
$$

where $R_{\mathrm{a}}$ and $R_{\mathrm{q}}$ are the values of roughness $(\mathrm{nm}), Z_{i}, j$ is the deviation from the average height relative to a mean plane and $N$ is the number of points in the image. For each film (CT, AS, WS, OS, CT-AS, CT-OS and CT-WS), three different samples were produced, of which three different areas were analyzed $(5 \mu \mathrm{m}, 1 \mu \mathrm{m}$ and $0.5 \mu \mathrm{m})$ and the average value was calculated.

Mechanical Properties

Young's modulus and hardness of films were obtained using a nanoindentation tester (TTX-NHT, Peseux, Switzerland). Indentation was performed by applying a maximum load of $5 \mathrm{mN}$, loading and unloading rate of $7.5 \mathrm{mN} / \mathrm{min}$ and a pause of $35 \mathrm{~s}$. A Berkovich diamond tip of pyramidal geometry and triangular base, with tip radius of $100 \mathrm{~nm}$ was used to obtain a loading and unloading curve (Figure 1).

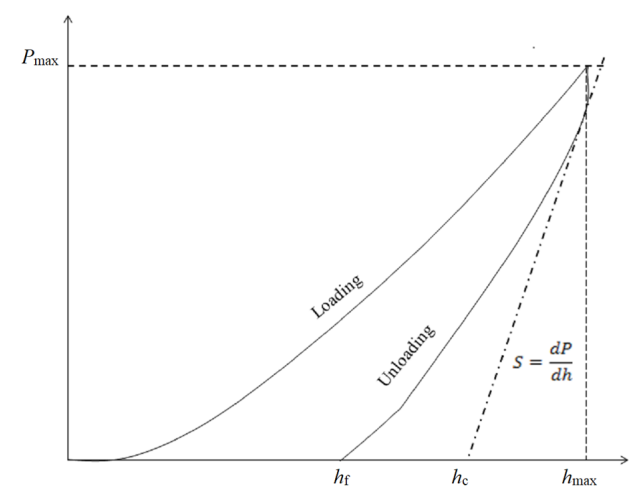

Figure 1. Curve of loading and unloading used to measure films mechanical properties. 
From this figure, the maximum load $\left(P_{\max }\right)$, the total penetration at maximum load $\left(h_{\max }\right)$, stiffness of the contact discharge start $(S)$, contact area (under the curve, $A_{\mathrm{c}}$ ), residual displacement after indenter unloading $\left(h_{\mathrm{f}}\right)$, real contact depth $\left(h_{\mathrm{c}}\right)$ and the elastic subsidence around the contacting surface $\left(h_{\mathrm{s}}\right)$ were obtained [21].

Hardness was calculated using Equation (10), whereas Young's modulus was calculated from Equations (11) and (12):

$$
\begin{gathered}
H=\frac{P_{\max }}{A \times h c} \\
E_{\mathrm{r}}=\frac{S \sqrt{\pi}}{2 \sqrt{A c}} \\
E_{\mathrm{m}}=\frac{1-v^{2}}{\frac{1}{E_{\mathrm{r}}}-\frac{1-v^{2}}{E_{\mathrm{i}}}}
\end{gathered}
$$

where $H(\mathrm{MPa})$ is the film's hardness, $E_{\mathrm{m}}$ is the elastic modulus (GPa), $E_{\mathrm{r}}$ is the reduced modulus $(\mathrm{GPa}), S$ is the initial unloading stiffness in the load curve, $v$ is the Poisson's ratio for polymeric samples estimated as $0.35, E_{\mathrm{i}}$ is the elastic modulus of $1141 \mathrm{GPa}$ for the indentation [22]. Tests were conducted in five different spots of three different films and average values were calculated.

\subsubsection{Chemical Properties}

Chemical interaction of $\mathrm{CT}$ with the three different types of starch was analyzed by Raman spectroscopy (Yvon Horiba, Edison, NJ, USA) coupled to a microscope (Olympus BX 41, Olympus Corporation, Shinjuku-ku, Tokyo, Japan). Samples were irradiated using a $735 \mathrm{~nm}$ laser with a $50 \times$ objective, a numerical range of 0.55 and a yield of $702 \mathrm{~nm}$ in diffraction; spectral resolution of $0.16 \mathrm{~cm}^{-1}$ was used, using a detector charge coupled (CCD) device with a spectral range of 450-950 nm. The confocal aperture and the entrance slit of the monochromator were kept constant at $400 \mu \mathrm{m}$. Readings were taken in a spectral range of $200-4000 \mathrm{~cm}^{-1}$ [18]. The program Spekwin 32 (Oberstdorf, Germany) was used for data treatment.

\subsubsection{Antimicrobial Activity}

Antimicrobial activity was evaluated following the methodology of Hernández-Hernández [23]. Briefly, $10 \mathrm{~mL}$ of trypticase soy agar $(0.8 \% w / v$, Bioxon, Cuautitlan, México) was inoculated with $500 \mu \mathrm{L}$ of $L$. innocua solution $\left(10^{7} \mathrm{CFU} / \mathrm{mL}\right)$, subsequently poured onto plates containing solidified agar $(1.5 \% w / v)$. Discs from each edible film $(25 \mathrm{~mm}$ in diameter) were placed on top of the soft agar layer, incubated at $37^{\circ} \mathrm{C}$ for $48 \mathrm{~h}$, the growth inhibition zone was measured using Vernier calipers.

\subsubsection{Statistical Analysis}

For each test three edible films samples were analyzed, conducting measurements at five different points (ends and center). Data were evaluated by one-way analysis of variance (ANOVA) and significant differences were analyzed by the Tukey test $(p<0.05)$.

\section{Results and Discussion}

\subsection{Starch Characterization}

The amylose content for WS, AS and OS were 7.1\% $\pm 0.9 \%, 27.5 \% \pm 1.6 \%, 15.7 \% \pm 0.9 \%$, respectively. According to $\mathrm{Li}$ et al. [24] and Cano et al. [25] retrogradation depends on ordered helical aggregation of amylose and amylopectin chains and increasing crystalline state and the higher the percentage of amylose the greater the extent of retrogradation, resulting in films with poor mechanical and barrier properties. Thus, starches with increased amylopectin content may minimize these effects. Due to the hydrophilic nature of starch, its resulting films show high WVP and to improve this property modified starches were used [26]. Modification involves introduction of functional groups into the 
starch molecule, AS showed $6.46 \% \pm 0.13 \%$ of acetylation, equivalent to a DS $=0.14 \pm 0.01$, whereas OS contained $0.073 \% \pm 0.005 \%$ of carboxyl groups and $0.074 \% \pm 0.006 \%$ of carbonyl groups. The presence of carboxyl groups within the starch molecule interrupts amylose and amylopectin linear sections, producing a reduced tendency to intermolecular association, promoting hydration of the granule [27]. Modified starches functional groups may interact with other components of edible films and hence alter their mechanical and barrier properties.

\subsection{Physical Characterization}

Films containing the mixtures CT-WS and CT-OS showed decreased luminosity ( $L$ value) whereas those made with CT-AS mixture increased the $L$ value (Table 1). Color is important to assess the application of the films as this will affect the appearance of the product over which films are applied.

Table 1. Color parameters of edible films made from $\mathrm{CH}$-only, starches-only and mixtures $\mathrm{CH}$-starches $(1: 3 w / w)$ ratio, respectively.

\begin{tabular}{ccccc}
\hline Edible Film & $\boldsymbol{L}^{*}$ & $\boldsymbol{a}^{*}$ & $\boldsymbol{b}^{*}$ & $\boldsymbol{\Delta} \boldsymbol{E}^{*}$ \\
\hline CT & $91.37 \pm 0.15^{\mathrm{a}, \mathrm{b}}$ & $-1.15 \pm 0.34^{\mathrm{b}}$ & $4.38 \pm 0.14^{\mathrm{b}}$ & $4.58 \pm 0.17^{\mathrm{b}, \mathrm{c}}$ \\
OS & $91.06 \pm 2.78^{\mathrm{a}, \mathrm{b}}$ & $-0.24 \pm 0.61^{\mathrm{a}}$ & $0.92 \pm 0.21^{\mathrm{c}}$ & $2.39 \pm 2.78^{\mathrm{c}, \mathrm{d}}$ \\
AS & $90.42 \pm 2.22^{\mathrm{a}, \mathrm{b}}$ & $-0.24 \pm 0.48^{\mathrm{a}}$ & $0.43 \pm 0.11^{\mathrm{c}}$ & $1.64 \pm 2.22^{\mathrm{d}}$ \\
WS & $93.06 \pm 2.02^{\mathrm{a}}$ & $-0.23 \pm 0.37^{\mathrm{a}}$ & $0.47 \pm 0.27^{\mathrm{c}}$ & $2.51 \pm 2.38^{\mathrm{c}, \mathrm{d}}$ \\
CT-OS & $88.87 \pm 0.32^{\mathrm{b}}$ & $-1.64 \pm 0.41^{\mathrm{c}}$ & $7.13 \pm 1.69^{\mathrm{a}}$ & $7.70 \pm 0.46^{\mathrm{a}}$ \\
CT-AS & $91.14 \pm 0.08^{\mathrm{a}, \mathrm{b}}$ & $-1.37 \pm 0.24^{\mathrm{b}, \mathrm{c}}$ & $6.70 \pm 0.85^{\mathrm{a}}$ & $6.66 \pm 0.13^{\mathrm{a}, \mathrm{b}}$ \\
CT-WS & $90.26 \pm 0.73^{\mathrm{a}, \mathrm{b}}$ & $-1.32 \pm 0.54^{\mathrm{b}}$ & $4.83 \pm 0.83^{\mathrm{b}}$ & $5.55 \pm 0.68^{\mathrm{a}, \mathrm{b}}$ \\
\hline
\end{tabular}

Notes: CT, Chitosan; OS, Oxidized starch; AS, Acetylated starch; WS, Waxy starch. ${ }^{\text {a-d }}$ : used next to reported values, indicate that if the same letter appears in the same column, the values compared are not significantly different $(p>0.05)$.

Films prepared from WS, OS and AS did not exhibit significant difference $(p<0.05)$ in $L$ value. This is consistent with a report by Levien-Vanier et al. [28], who found that starch subjected to an oxidation process does not change color parameters. The observed $a^{*}$ value indicates a reddish color of the starch-only films but significant difference $(p<0.05)$ was found when compared to CT-only films. Similar to the $L$ value, the presence of CT mixed with any of the starches tested, affected films appearance, causing increased yellowish color. This result agrees with Kurek et al. [29], where CT incorporated to whey protein isolate films provided yellow tint, while increasing the value of $\Delta E^{*}$. Luminosity, chromatic parameters $\left(a^{*}, b^{*}\right)$ and $\Delta E^{*}$ for CT-starches films (Table 1) are similar those previously reported [30].

Thickness, WVP and solubility are shown in Table 2. Thickness can affect barrier properties, particularly WVP due to differences between the water vapor pressure below the film and that of the moisture build-up above the film [16]. To obtain films with similar thickness, same suspension volumes were used. However, films prepared with mixtures $\mathrm{CH}$-starches exhibited lower thickness that those prepared with starches only (Table 2).

AS films showed the highest thickness $(112 \pm 11 \mu \mathrm{m})$ due to the introduction of acetyl groups that promote spacing between starch chains, reduction of retrogradation and syneresis and thus, more water retention within the film after drying [31]. Moreover, high swelling of starch granules leads to higher film thicknesses [32]. Thus, AS was expected to show the best barrier properties but instead it showed the highest WVP (Table 2). High WVP and solubility were attributed to the degree of substitution $(0.142 \pm 0.005)$, where the introduction of acetyl groups into the starch molecule prevented inter-chains association, facilitating water penetration inside AS films, which may explain its low retrogradation [33]. CT films presented the smallest thickness and solubility associated to its deacetylation extent $(\geq 75 \%)$, since it is known that CT solubility and WVP decrease with the number of amino groups [34]. 
Table 2. Physical properties of edible films made from $\mathrm{CH}$-only, starches-only and mixtures $\mathrm{CH}$-starches $(1: 3 w / w)$ ratio, respectively.

\begin{tabular}{|c|c|c|c|}
\hline Edible Film & Thickness $(\mu \mathrm{m})$ & Solubility (\%) & Water Vapor Permeability $\times 10^{9}(\mathrm{~g} \mathrm{~mm} /(\mathrm{s} \mathrm{m} \mathrm{Pa}))$ \\
\hline $\mathrm{CT}$ & $66 \pm 6^{a}$ & $17.07 \pm 1.38^{\mathrm{a}}$ & $1.65 \pm 0.47^{\mathrm{a}}$ \\
\hline OS & $105 \pm 26^{b}$ & $80.06 \pm 2.37^{b}$ & $1.00 \pm 0.39^{\mathrm{a}}$ \\
\hline AS & $128 \pm 14^{b}$ & $39.57 \pm 1.68^{c}$ & $2.06 \pm 0.61^{b}$ \\
\hline WS & $112 \pm 11^{b}$ & $40.97 \pm 3.41^{\mathrm{c}}$ & $1.15 \pm 0.33^{\mathrm{a}}$ \\
\hline CT-OS & $74 \pm 7^{\mathrm{a}}$ & $26.77 \pm 1.40^{\mathrm{d}}$ & $1.18 \pm 0.48^{\mathrm{a}}$ \\
\hline CT-AS & $93 \pm 13^{b}$ & $32.02 \pm 2.2^{c}$ & $1.11 \pm 0.03^{\mathrm{a}}$ \\
\hline CT-WS & $81 \pm 5^{b}$ & $27.71 \pm 1.56^{\mathrm{d}}$ & $1.32 \pm 0.54^{\mathrm{a}}$ \\
\hline
\end{tabular}

Notes: CT, Chitosan; OS, Oxidized starch; AS, Acetylated starch; WS, Waxy starch. ${ }^{\text {a-d }}$ : used next to reported values, indicate that if the same letter appears in the same column, the values compared are not significantly different $(p>0.05)$.

Starch films changed their properties by CT incorporation, decreasing thickness, WVP and solubility. WS-CT and AS-CT films showed high thickness values, associated to high swelling of starch granules produced by the high amylopectin content of WS and the presence of acetyl groups in AS $[27,35]$. When CT was used in mixture with AS, the films revealed low WVP, improving this barrier property, while OS-CT highly affected solubility due to the carboxyl groups in its structure leading to increased hydrophilicity. According to Liu et al. [36], starch oxidation results in partial depolymerization and this could cause structural weakening of OS granules increasing molecular mobility [36]. AS and WS with CT Raman spectrogram shows interactions of AS and WS with CT amino groups leading to more soluble films, while OS interacted with amino groups and with hydroxyl groups at a higher extent than the other starches, making the films less soluble. These phenomena are associated to $\mathrm{CT}$ interactions with each type of starch (larger amount and type of bonds formed between CT and OS than those formed using WS) [37]. According to Alves et al. [38], CT interactions with starch depend on the functional groups that characterize each of the starches used.

\subsection{Mechanical Properties}

Nanoindentation can provide detailed information from a high local deformation, which is of great importance for systems with limited dimensionality, such as thin films and coatings. This technique permits identification of transition zones between phases in heterogeneous materials, specifically on their surface or interface at very low sensitivity ranges [39]. Thus, mechanical properties of samples showing small local deformation such as thin coatings can be successfully characterized by analyzing their surface [40]. CT-OS films exhibited the lowest surface hardness, whereas AS-film was the hardest because of its higher amylose content (Table 3). This effect agrees with Lopez et al. [26], who found that linear amylose chains show high tendency to interact via hydrogen bonds, resulting in stiffer and stronger films than those presenting high amylopectin content. From Table 3, it is noted that CT addition produced films with reduced surface hardness, attributed to increased molecular mobility among polysaccharide chains [40]. A study established correlations between mechanical properties and polymers crystallinity, showing that vitreous materials exhibit low hardness, whereas semicrystalline samples hardness tend to rise with increasing crystallinity [41].

WS edible film surface revealed the highest hardness value, attributed to its amylopectin composition, since the higher content the more rigid structure is presented due to its degree of crystallinity. OS and AS edible films contain lower amylopectin proportion than WS and this was reflected in less rigid surface structures and therefore low hardness [42]. CT exhibits low crystallinity $(7.3 \% \pm 0.5 \%)$ [18] that is reduced in mixtures with starch films by interruption of amylopectin chains, preventing structural rearrangement of starch during film drying process. The addition of CT in the starch films resulted decreased Young's modulus of films surface. Surface elastic modulus was similar for mixtures CT-OS and CT-AS but lower than that of starch films and these changes may be attributed to cross links of polysaccharides network. This phenomenon is similar to that observed by Alvarado-González et al. [43], when producing edible films based on Aloe Vera gel/gellan gum, 
observing surface increased hardness and decreased surface elastic modulus, as compared to their individual components.

Table 3. Hardness and Young's modulus of edible films based on starch, $\mathrm{CH}$ and $\mathrm{CH}$-starches mixtures $(1: 3$ ratio, $w / w)$.

\begin{tabular}{ccc}
\hline Edible Film & Hardness $(\mathbf{M P a})$ & Young Modulus $(\mathrm{GPa})$ \\
\hline CT & $5.87 \pm 0.46^{\mathrm{a}}$ & $0.07 \pm 0.01^{\mathrm{a}}$ \\
OS & $168.90 \pm 3.00^{\mathrm{b}}$ & $2.76 \pm 0.15^{\mathrm{b}}$ \\
AS & $198.77 \pm 22.55^{\mathrm{c}}$ & $4.31 \pm 0.35^{\mathrm{c}}$ \\
WS & $180.99 \pm 4.31^{\mathrm{c}}$ & $3.36 \pm 0.12^{\mathrm{c}}$ \\
CT-OS & $2.30 \pm 0.19^{\mathrm{a}}$ & $0.11 \pm 0.06^{\mathrm{a}}$ \\
CT-AS & $3.97 \pm 0.73^{\mathrm{a}}$ & $0.09 \pm 0.01^{\mathrm{a}}$ \\
CT-WS & $9.54 \pm 1.42^{\mathrm{a}}$ & $0.44 \pm 0.03^{\mathrm{d}}$ \\
\hline
\end{tabular}

Notes: CT, Chitosan; OS, Oxidized starch; AS, Acetylated starch; WS, Waxy starch. ${ }^{\text {a-d }}$ : used next to reported values, indicate that if the same letter appears in the same column, the values compared are not significantly different $(p>0.05)$.

\subsection{Topography Properties}

From AFM, it was observed that CT-films exhibited the lowest surface roughness (Figure 2D) and considering that $R_{\mathrm{q}}$ or $R_{\mathrm{a}}<10$ for all films, they are regarded as exhibiting a smooth surface [44]. $\mathrm{CT}$ addition promoted films displaying smoother surface (Figure 2A-C), whereas OS-CT-films showed a mild roughness increase $\left(9.7 \%\right.$ for $R_{\mathrm{a}}$ and $20.7 \%$ for $R_{\mathrm{q}}$ ) compared to CT films (Figure $2 \mathrm{~B}, \mathrm{D}$ ). Bonilla et al. [45] reported that CT addition to starch produced smoother film surfaces because of high compatibility between the two polymers. AS films (Figure $2 \mathrm{G}$ ) showed the highest roughness values, associated to structural rearrangement due to acetylation, resulting in greater space occupation by the starch molecules [46].

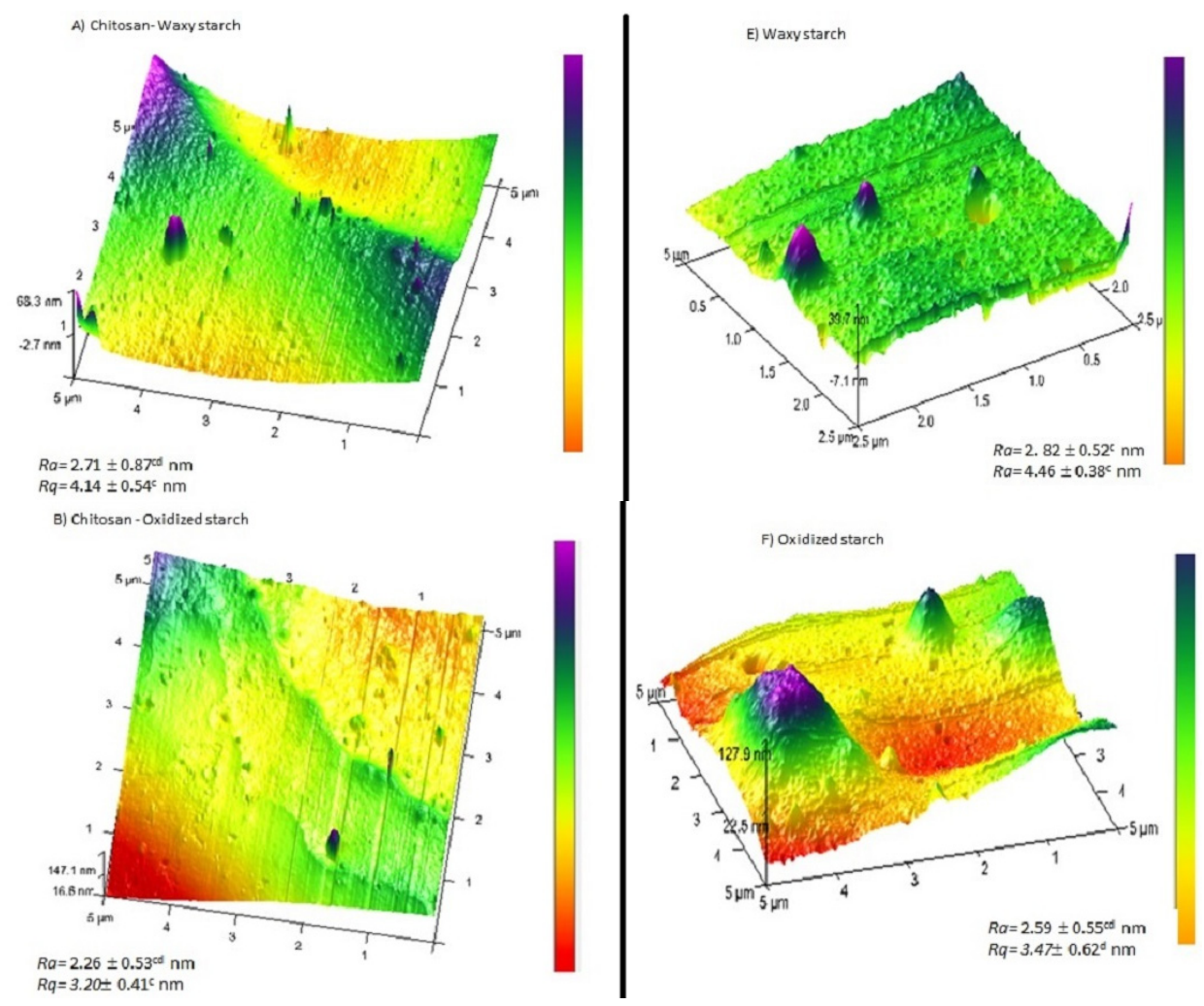

Figure 2. Cont. 

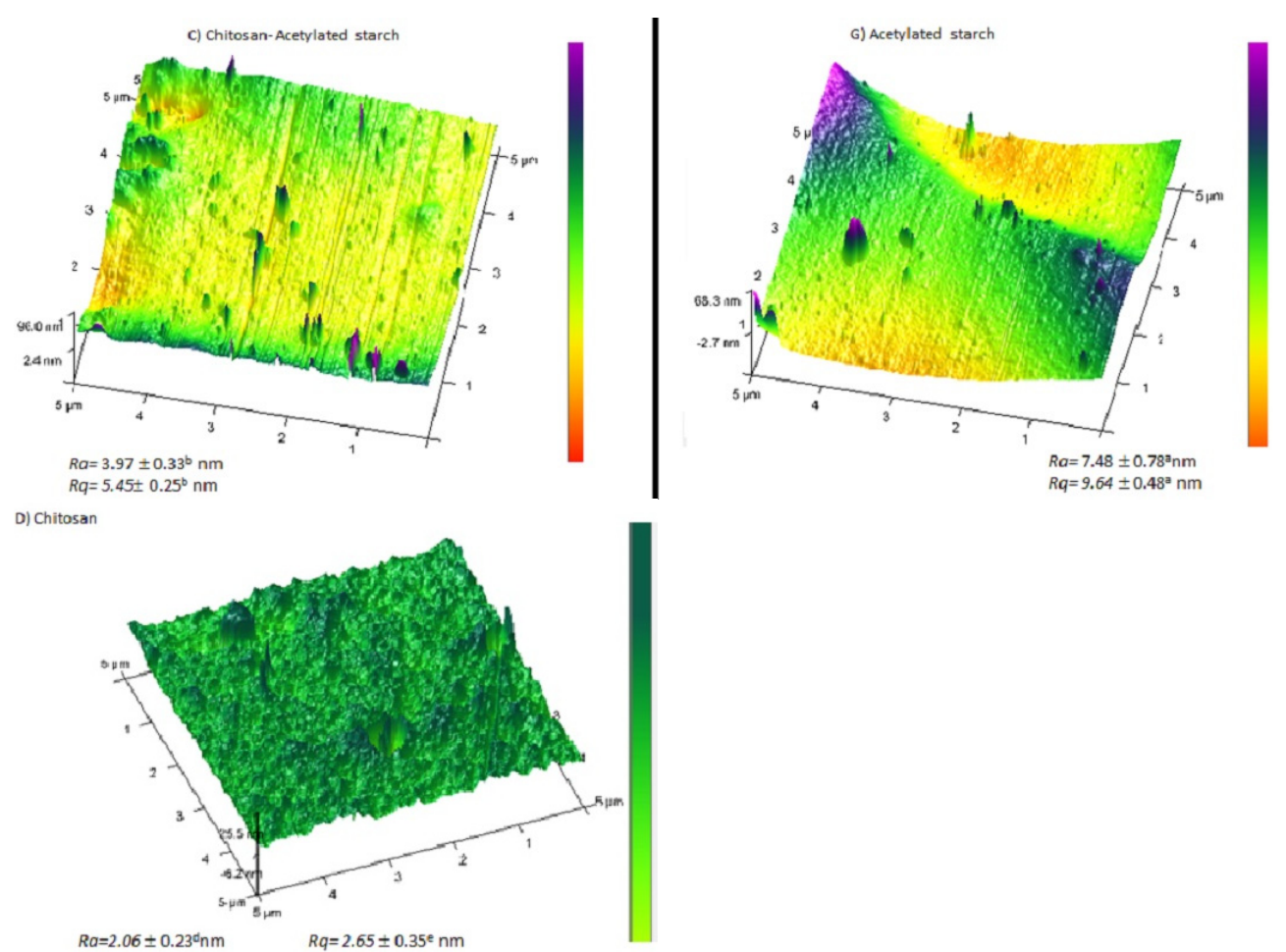

Figure 2. AFM Micrographs of edible films: (A) Chitosan-Waxy starch; (B) Chitosan-Oxidized starch; (C) Chitosan-Acetylated starch; (D) Chitosan; (E) Waxy starch; (F) Oxidized Starch; (G) Acetylated starch. Superscript letters a-e used next to reported values indicate that if the same letter appears in the same parameter, the values compared are not significantly different $(p>0.05)$.

\subsection{Raman Spectroscopy}

From spectrograms of the different films, chemical interaction between chitosan and starch was noticed, in agreement with other studies [47]. Raman spectroscopy identified starch interactions in edible films with or without $\mathrm{CT}$, by signals appearance or disappearance depending on functional groups. Spectral comparison of the three CT-starch mixtures are shown in Figure 3a, where differences confirm that the type of starch affected the chemical structure of edible films and therefore mechanical, barrier and physical properties. For instance, WS-CT films did not show any signal at 533, 756 and $1398 \mathrm{~cm}^{-1}$ which are attributed to torsion of the $\mathrm{C}-\mathrm{O}$ bond, bending of $\mathrm{C}-\mathrm{C}-\mathrm{O}$ bonds and $\mathrm{C}-\mathrm{C}-\mathrm{H}$ bonds, respectively [48]. Thus, in WS-CT films CT interacted in a different way compared to OS-CT and AS-CT films, because of the presence of carboxyl, carbonyl and acetyl groups in modified starches.

Colussi et al. [31] concluded that important interactions occur among hydroxyl groups of C6, C2 and $\mathrm{C} 3$ of glucose units of starch, being $\mathrm{C} 6$ the most reactive due to steric hindrance of $\mathrm{C} 2$ and $\mathrm{C} 3$. Figure $3 \mathrm{~b}$ shows the spectrum of films made with WS-CT mixture, where signals characteristic of CT disappeared at 421, 924 and $1409 \mathrm{~cm}^{-1}$ indicating chemical interactions and were attributed to bending out of plane of $\mathrm{OH}$, the pyran ring $\gamma(\mathrm{OH})+\gamma(\phi)$, vibrations of $\mathrm{CN}$ bonds and symmetric vibrations $\delta\left(\mathrm{CH}_{3}\right)+\delta(\mathrm{CH})$, respectively. WS-CT films showed a peak at $1737 \mathrm{~cm}^{-1}$, that was not observed for films made from CT or WS only and according to Zhang et al. [49] is the stretching of $\mathrm{C}=\mathrm{O}$ groups. This suggests a possible reaction of a methyl group of $\mathrm{CT}$ with the $\mathrm{C} 6 \mathrm{OH}$ of $\mathrm{WS}$, leaving a free $\mathrm{C}=\mathrm{O}$ group in CT-WS mixture.

From Figure 3c, the CT signal at $542 \mathrm{~cm}^{-1}$ disappeared, which represents vibrations out of the flexion plane of the $\mathrm{NH}$ and $\mathrm{C}=\mathrm{O}$ groups [46], that interacted with AS, possibly associated to hydrogen bonds formation. The acetyl groups of AS may also interact with the $\mathrm{NH}_{2}$ groups of $\mathrm{CT}$ to form new links. In addition, the oxygen of the carbonyl group of CT bearing partial negative charge can interact with $\mathrm{OH}$ groups of starch [18]. 
Signals at 890 and $1220 \mathrm{~cm}^{-1}$ (Figure 3c), characteristic of glucopyranose ring and vibrations in the plane of bending $\gamma(\mathrm{OH} \ldots \mathrm{O})$ of $\mathrm{CT}$ [50] are not observed. This effect is associated to a decreased signal of AS at 653 and $1202 \mathrm{~cm}^{-1}$, attributed to the $\mathrm{C}-\mathrm{C}$ and $\mathrm{C}-\mathrm{O}$. bonds of the pyranose ring [49], suggesting that the ring breaks and loses its structure. More studies are needed to confirm this assumption. In the CT-OS spectrogram (Figure 3d) signals at 542 and $778 \mathrm{~cm}^{-1}$, which were observed in the OS film were not detected in the mixture and according to Almeida [48] these signals are attributed to $\mathrm{C}-\mathrm{C}-\mathrm{O}$ bonds and a stretch of the pyranose ring of starch, respectively, suggesting chemical interaction. Another signal lost in the CT-OS spectrogram was that at $896 \mathrm{~cm}^{-1}$ attributed to $\mathrm{CH}_{2} \gamma(\Phi)+\rho\left(\mathrm{CH}_{2}\right)$ of CT [47]. In addition, a new signal appeared at $1730 \mathrm{~cm}^{-1}$, attributed to $\mathrm{OH}$ groups [48]. It must be bore in mind that starch-CT mixtures were heated at $90{ }^{\circ} \mathrm{C}$ for $10 \mathrm{~min}$ at $\mathrm{pH}$ about 3.5, leading to partial hydrolysis of starch glycosidic bonds, as reported by Hong et al. [51]. These authors stated that terminal linkages are more susceptible than those within the chains and thus glycosidic bond rupture (starch hydrolysis) increases the number of $-\mathrm{OH}$ groups in free $\mathrm{C} 1, \mathrm{C} 4$ and $\mathrm{C} 6$ atoms and this may explain our findings. This section may be divided by subheadings. It should provide a concise and precise description of the experimental results, their interpretation as well as the experimental conclusions that can be drawn.

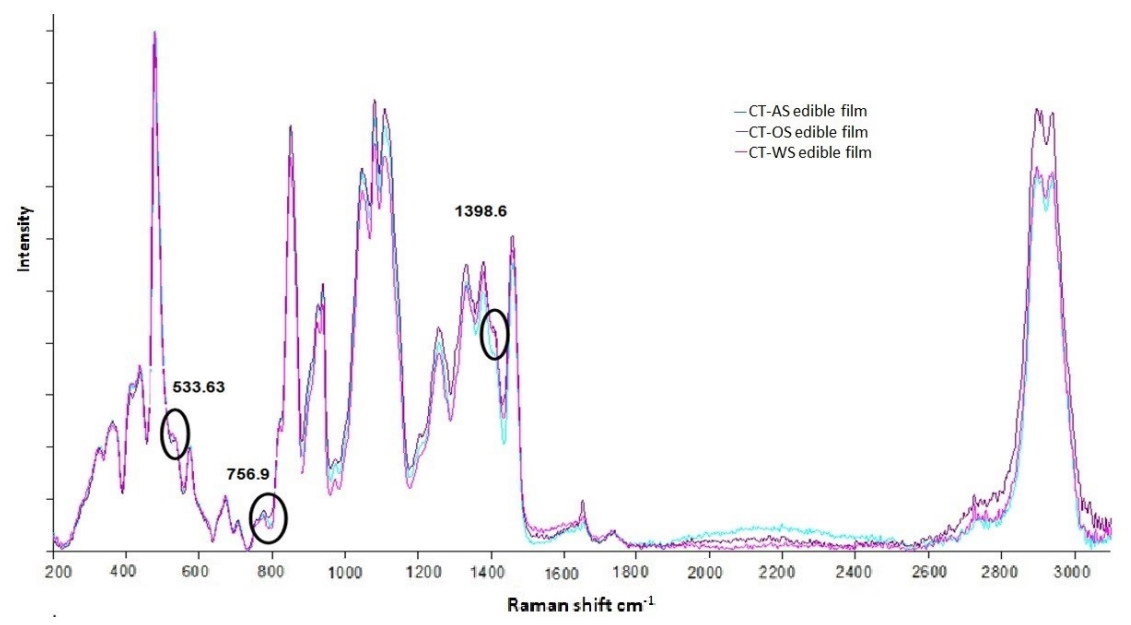

(a)

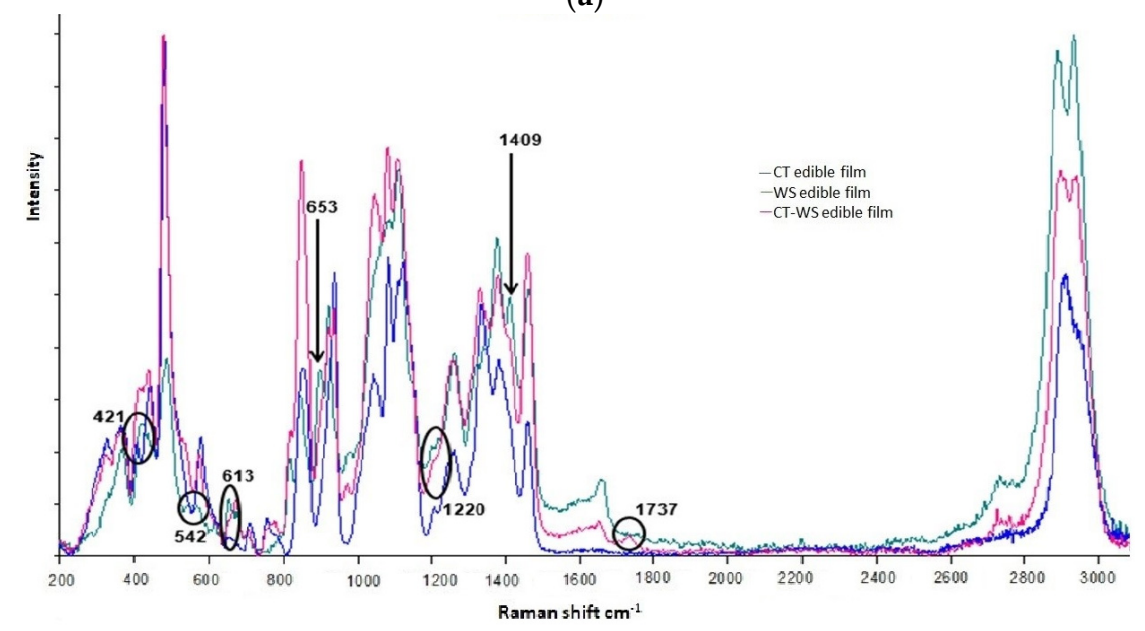

(b)

Figure 3. Cont. 


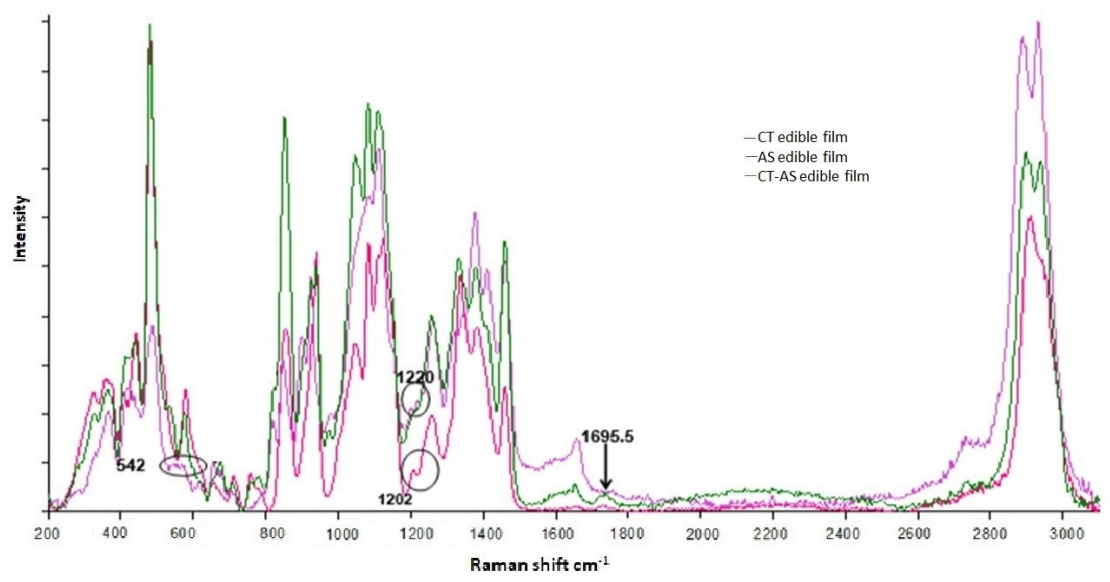

(c)

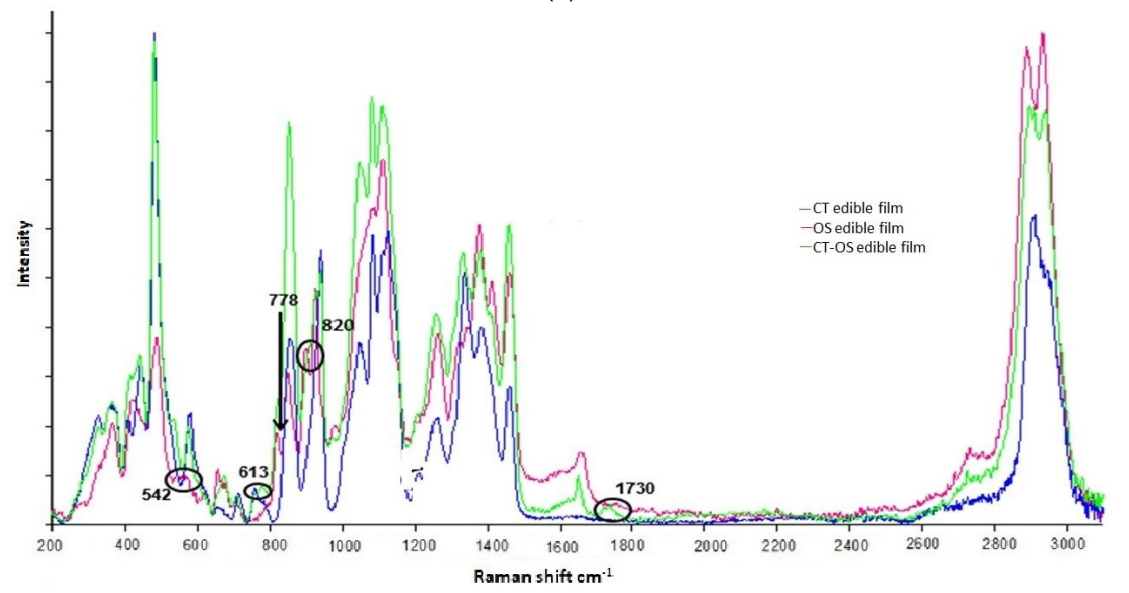

(d)

Figure 3. Raman spectroscopy of edible films based on starch, $\mathrm{CH}$ and $\mathrm{CH}$-starches mixtures (1:3 ratio, $w / w)$ : (a) CT-starch mixtures; (b) solid line CT, dashed line WS, dotted line CT-WS; (c) solid line CT, dashed line AS, dotted line CT-AS; (d) solid line CT, dashed line OS, dotted line CT-OS.

\subsection{Antimicrobial Activity}

The presence of $\mathrm{CT}$ in edible films allowed them to show antimicrobial activity against L. innocua, whereas films made with only starch did not show inhibition (Table 4). CT films showed the highest bactericidal activity (Figure 4) and its mechanism was attributed to the amino groups in its molecular structure being attached to the cell membrane through electrostatic interactions [52]. Other studies found that after $6 \mathrm{~h}$ of exposure to CT, it caused cells morphological alterations, where most cells showed enlarged and spongy walls with remarkable signs of lysis [53].

Table 4. Inhibitory effect of EF against Listeria innocua.

\begin{tabular}{cc}
\hline Edible Films & Average Diameter $(\mathbf{c m})$ \\
\hline OS & 0 \\
AS & 0 \\
WS & 0 \\
CT & $5.4 \pm 0.3^{\mathrm{a}}$ \\
CT-OS & $3.7 \pm 0.5^{\mathrm{b}}$ \\
CT-AS & $4.2 \pm 0.4^{\mathrm{b}}$ \\
CT-WS & $3.9 \pm 0.4^{\mathrm{b}}$ \\
\hline
\end{tabular}

Notes: CT, Chitosan; OS, Oxidized starch; AS, Acetylated starch; WS, Waxy starch. ${ }^{\mathrm{a}, \mathrm{b}}$ : used next to reported values, indicates that if the same letter appears in the same column, the values compared are not significantly different $(p>0.05)$. 


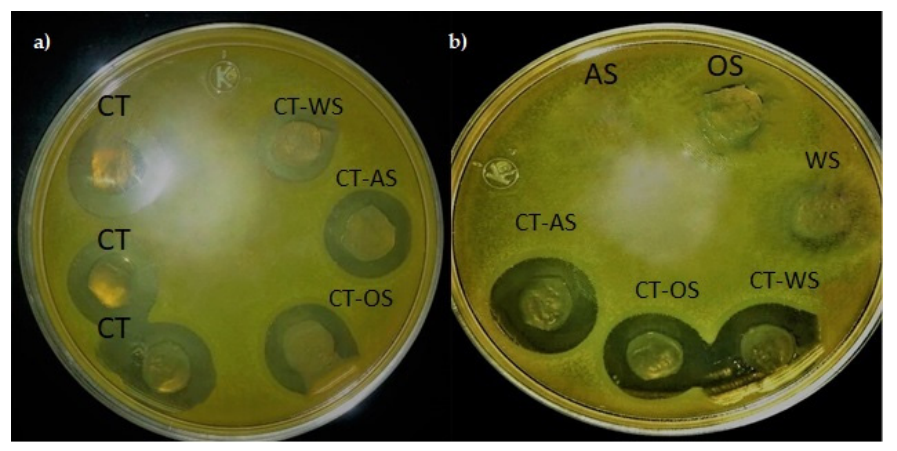

Figure 4. Inhibition halos of edible films based on starch, $\mathrm{CH}$ and $\mathrm{CH}$-starches mixtures (1:3 ratio, w/w) against Listeria innocua. CT: Chitosan; OS: Oxidized starch; AS: Acetylated starch; WS: Waxy starch.

(a) CT versus CT-starch mixtures; (b) Starches versus CT-starch mixtures.

\section{Conclusions}

The effect of $\mathrm{CT}$ addition on edible films based on native and modified starches has not been studied. This study demonstrated that $\mathrm{CT}$ addition on starch affected surface edible films mechanical and barrier properties, depending on the type of starch and its chemical modification. These properties were altered due to chemical interactions and structural changes of starch-CT edible films. Additionally, AS and WS interacted with CT amino groups producing more soluble films. The mixture CT-OS showed partial hydrolysis of starch associated to low $\mathrm{pH}$ and high temperature treatment, whereas films made from CT-AS mixture exhibited chemical interaction between $\mathrm{NH}_{2}$ and $\mathrm{OH}$ groups. CT-AS mixture showed good barrier and mechanical properties as well as the highest antimicrobial effect against Listeria, which suggests its further application in food products to maintain their safety.

Acknowledgments: Monserrat Escamilla-García wishes to express their gratitude for the CONACyT scholarship provided. This research was financed through the project CB-166751 from CONACyT. The authors also wish to thank the Centro de Nanociencias y Micro y Nanotecnologías (CNMN) IPN for supporting the facilities for this research work and for technical assistance.

Author Contributions: Monserrat Escamilla-García carried out the experimental part of the research project and manuscript writing. Andrea Reyes-Basurto collaborated in the experimental part of this project and Georgina Calderón-Domínguez conducted Raman spectroscopy, analyses and their interpretation. Elvia Hernández-Henández collaborated with the AFM measurements and their interpretation. Blanca E. García-Almendárez developed microbiological experiments and their interpretation. Giovanna Rossi-Márquez performed mechanical properties of films. Carlos Regalado-González advised on planning of experiments and manuscript writing.

Conflicts of Interest: The authors declare no conflict of interest.

\section{References}

1. Fakhouri, F.; Martilli, S.; Caon, T.; Velasco, J. Edible films and coatings base on starch/gelatin: Film properties and effect of coatings on quality of refrigerated red crimson grapes. Postharvest Biol. Technol. 2015, 109, 57-64. [CrossRef]

2. Souza, B.; Cerqueira, M.; Martins, J.; Casariego, A.; Teixeira, J.; Vicente, A. Influence of electric fields on the structure of chitosan edible coatings. Food Hydrocoll. 2010, 24, 330-335. [CrossRef]

3. Mason, W. Starch use in foods. In Starch, 3rd ed.; Academic Press: Burlington, MA, USA, 2009; pp. 745-795.

4. Pérez-Gallardo, A.; Bello-Pérez, L.; García-Almendárez, B.; Montejano-Gaitán, G.; Barbosa-Cánovas, G.; Regalado-González, C. Effect of structural characteristics of modified waxy corn starches on rheological properties, film-forming solutions and on water vapor pemeability, solubility and opacity of films. Starch-Särke 2012, 64, 27-36. [CrossRef]

5. Li, G.; Huang, J.; Chen, T.; Wang, X.; Zhang, H.; Chen, Q. Insight into the interaction between chitosan and bovine serum albumin. Carbohydr. Polym. 2017, 176, 75-82. [CrossRef] [PubMed]

6. Kanatt, R.; Chander, R.; Sharma, A. Chitosan and mint mixture: A new preservative for meat and meat products. Food Chem. 2007, 107, 845-852. [CrossRef] 
7. Ma, Z.; Garrido-Maestu, A.; Casey Jeong, K. Application, mode of action and in vivo activity of chitosan and its micro- and nanoparticles as antimicrobial agents: A review. Carbohydr. Polym. 2017, 176, 257-265. [CrossRef] [PubMed]

8. Jost, V.; Kobsik, K.; Schmid, M.; Noller, K. Influence of plasticizer on the barrier on the barrier, mechanical and grease resistance properties of alginate cast films. Carbohydr. Polym. 2014, 110, 309-319. [CrossRef] [PubMed]

9. Sánchez-Rivera, M.; Almanza-Benitez, S.; Bello-Pérez, L.; Mendez-Montealvo, G.; Núñez-Santiago, M.C.; Rodríguez-Ambriz, S.L.; Gutierrez-Meráz, F. Acetylation of banana (Musa paradisiaca L.) and corn (Zea mays L.) starches using a microwave heating procedure and iodine as catalyst: II. Rheological and structural studies. Carbohydr. Polym. 2013, 92, 1256-1261. [CrossRef] [PubMed]

10. Zhou, Y.; Li, X.; Lv, Y.; Shi, Y.; Zeng, Y.; Li, D.; Mu, C. Effect of oxidation level on the inclusion capacity and solutionstability of oxidized amylose in aqueous solution. Carbohydr. Polym. 2016, 138, 41-48. [CrossRef] [PubMed]

11. Sandhu, K.; Kaur, M.; Singh, N.; Lim, S.-T. A comparison of native and oxidized normal and waxy corn starches: Physicochemical, thermal, morphological and pasting properties. LWT Food Sci. Technol. 2008, 41, 1000-1010. [CrossRef]

12. Megazyme, Setting New Standards in Test Technology. Available online: https://www.megazyme.com/ header-utilities/worldwide-distributors (accessed on 14 March 2016).

13. Bourbon, A.I.; Pinheiro, A.C.; Cerqueira, M.A.; Rocha, C.M.R.; Avides, M.C.; Quintas, M.A.C.; Vicente, A.A. Physicochemical characterization of chitosan based films incorporating bioactive compounds of different molecular weight. J. Food Eng. 2011, 106, 111-118. [CrossRef]

14. Xu, Y.; Kim, K.; Hanna, M.; Nag, D. Chitosan-starch composite film: Preparation and characterization. Ind. Crop. Prod. 2005, 21, 185-192. [CrossRef]

15. Hunter, R.S.; Harold, R.W. The Measurement of Appearance, 2nd ed.; John Wiley \& Sons: New York, NY, USA, 1987.

16. Gutiérrez, T.J.; Tapia, M.S.; Pérez, E.; Famá, L. Structural and mechanical properties of edible films made from native and modified cush-cush yam and cassava starch. Food Hydrocoll. 2015, 45, 211-217. [CrossRef]

17. ASTM E 96-80 Variability of Water Vapor Transmission Rates of Extruded Polystyrene Using ASTM E 96-80 (Desiccant Method); ASTM International: West Conshohocken, PA, USA, 2016.

18. Escamilla-García, M.; Calderón-Domínguez, G.; Chanona-Pérez, J.J.; Farrera-Rebollo, R.R.; Andraca-Adame, J.; Arzate-Vázquez, I.; Mendez-Mendez, J.V.; Moreno-Ruíz, L.A. Physical and structural characterisation of zein and chitosan edible films using nanotechnology tools. Int. J. Biol. Macromol. 2013, 61, 196-203. [CrossRef] [PubMed]

19. Ghamsemlou, M.; Khodaiyan, F.; Oromiehie, A. Physical, mechanical, barrier and thermal properties of polyol-plasticized biodegradable edible film made from kefiran. Carbohydr. Polym. 2011, 84, 477-483. [CrossRef]

20. Morris, V. Atomic force microscopy (AFM) and related tools for the imaging of foods and beverages on the nanoscale. In Nanotechnology in the Food, Beverage and Nutraceutical Industries; Woodhead Publishing: Cambridge, UK, 2012; pp. 99-148. [CrossRef]

21. Beake, B.; Ranganathan, N. An investigation of the nanoindentation and nano/micro-tribological behaviour of monolayer, bilayer and trilayer coatings on cemented carbide. Mater. Sci. Eng. A 2006, 423, 46-51. [CrossRef]

22. Lavorgna, M.; Piscitelli, F.; Mangiacapra, P.; Buonocore, G. Study of the combined effect of both clay and glycerol plasticizer on the properties of chitosan films. Carbohydr. Polym. 2010, 82, 291-298. [CrossRef]

23. Hernández-Hernández, E.; Regalado-González, C.; Vázquez-Landaverde, P.; Guerrero-Legarreta, I.; García-Almendárez, B.E. Microencapsulation, chemical characterization and antimicrobial activity of Mexican (Lippia graveolens H.B.K.) and European (Origanum vulgare L.) oregano essential oils. Sci. World J. 2014, 2014, 641814. [CrossRef] [PubMed]

24. Li, W.; Tian, X.; Wang, P.; Saleh, A.; Luo, Q.; Zheng, J.; Ouyang, S.; Zhang, G. Recrystallization characteristics of high hydrostatic pressure gelatinized normal and waxy corn starch. Int. J. Biol. Macromol. 2016, 83, 171-177. [CrossRef] [PubMed]

25. Cano, A.; Jiménez, A.; Cháfer, M.; Gónzalez, C.; Chiralt, A. Effect of amylose:amylopectin ratio and rice bran addition on starch films properties. Carbohydr. Polym. 2014, 111, 543-555. [CrossRef] [PubMed] 
26. López, O.V.; García, M.A.; Zaritzky, N.E. Film forming capacity of chemically modified corn starches. Carbohydr. Polym. 2008, 73, 573-581. [CrossRef] [PubMed]

27. Adebowale, K.; Olu-Owolabi, B.; Olawumi, E.; Lawal, O. Functional properties of native, physically and chemically modified breadfruit (Artocarpus artilis) starch. Ind. Crop. Prod. 2005, 21, 343-351. [CrossRef]

28. Levien Vanier, N.; da Rosa Zavareze, E.; Zanella Pinto, V.; Klein, B.; Torma Botelho, F.; Guerra Dias, A.R.M.; Elias, C. Physicochemical, crystallinity, pasting and morphological properties of bean starch oxidised by different concentrations of sodium hypochlorite. Food Chem. 2012, 131, 1255-1262. [CrossRef]

29. Kurek, M.; Galus, S.; Debeaufort, F. Surface, mechanical and barrier properties of bio-based composite films based on chitosan and whey protein. Food Packag. Shelf Life 2014, 1, 56-67. [CrossRef]

30. Jidri, M.; Hajji, S.; Ayed, B.H.; Lassoued, I.; Mbaerk, A.; Kammoun, M.; Souissi, N.; Masri, M. Physical, structural, antioxidant and antimicrobial properties of gelatin-chitosan composite edible films. Int. J. Biol. Macromol. 2014, 67, 373-379. [CrossRef]

31. Colussi, R.; Pinto, V.Z.; Halal, S.L.M.; Vanier, N.L.; Villanova, F.A.; Silva, R.M.; Zavareze, E.d.R.; Guerra Dias, A.R. Structural, morphological and physicochemical properties of acetylated high-, medium- and low-amylose rice starches. Carbohydr. Polym. 2014, 103, 405-413. [CrossRef] [PubMed]

32. Bertuzzi, M.; Armada, M.; Gottifredi, J. Physicochemical characterization of starch based films. J. Food Eng. 2007, 82, 17-25. [CrossRef]

33. Khalil Diop, C.I.; Li, H.L.; Xie, B.J.; Shi, J. Impact of the catalytic activity of iodine on the granule morphology, crystalline structure, thermal properties and water solubility of acetylated corn (Zea mays) starch synthesized under microwave assistance. Ind. Crop. Prod. 2010, 33, 302-309. [CrossRef]

34. Siang-Ying, C.; Be-Jen, W.; Ying-Ming, W. Antioxidant and antimicrobial edible zein/chitosan composite films fabricated by incorporation of phenolic compounds and dicarboxylic acids. LWT Food Sci. Technol. 2015, 63, 115-121. [CrossRef]

35. Lu, D.; Shen, X.; Cai, X.; Yan, F.; Lu, W.; Shi, Y. Effects of heat stress during grain filing on the structure an thermal properties of waxy maize starch. Food Chem. 2014, 143, 313-318. [CrossRef] [PubMed]

36. Liu, J.; Wang, B.; Lin, L.; Zhang, J.; Liu, W.; Xie, J.; Ding, Y. Functional, physicochemical properties and structure of cross-linked oxidized maize starch. Food Hydrocoll. 2014, 36, 45-52. [CrossRef]

37. Mei, J.; Yuan, Y.; Wu, Y.; Li, Y. Characterization of edible starch-chitosan film and its application in the storage of Mongolian cheese. Int. J. Biol. Macromol. 2016, 57, 5617-5621. [CrossRef] [PubMed]

38. Alves, D.V.; Mali, S.; Beléia, A.; Grossmann, E.M.A. Effect of glycerol and amylose enrichment on cassava starch film properties. J. Food Eng. 2007, 78, 941-946. [CrossRef]

39. Rovera, C.; Cozzolino, C.A.; Ghaani, M.; Morrone, D.; Olsson, R.T.; Farris, S. Mechanical behavior of biopolymer composite coatings on plastic films by depth-sensing indentation-A nanoscale study. J. Colloid Interface Sci. 2018, 512, 638-646. [CrossRef] [PubMed]

40. Cerqueira, M.A.; Souza, B.W.; Teixeira, J.A.; Vicente, A.A. Effect of glycerol and corn oil on physicochemical properties of polysaccharide films-A comparative study. Food Hydrocoll. 2012, 27, 175-184. [CrossRef]

41. Díez-Pascual, A.M.; Gómez-Fatou, M.A.; Ania, F.; Flores, A. Nanoindentation in polymer nanocomposites. Prog. Mater. Sci. 2015, 67, 1-94. [CrossRef]

42. Ji, Z.; Yu, L.; Liu, H.; Bao, X.; Wang, Y.; Chen, L. Effect of pressure with shear stress on gelatinization of starches with different amylose/amylopectin ratios. Food Hydrocoll. 2017, 72, 331-337. [CrossRef]

43. Alvarado-González, J.; Chanona-Pérez, J.J.; Welti-Chanes, J.; Calderón-Domínguez, G.; Arzate-Vázquez, I.; Gutierrez López, G.F.; Pacheco-Alcalá, L. Optical, Microstructural, Functional and Nanomechanical Properties of Aloe vera Gel/Gellan Gum Edible Films. Rev. Mex. Ing. Quim. 2012, 11, 193-210.

44. Unal, M.; Unver, B. Characterization of rock joint surface degradation under shear loads. Int. J. Rock Mech. Min. Sci. 2004, 41, 14-150. [CrossRef]

45. Bonilla, J.; Talón, E.; Atarés, L.; Vargas, M.; Chiral, A. Effect of the incorporation of antioxidants on physicochemical and antioxidant properties of wheat starch-chitosan films. J. Food Eng. 2013, 118, 271-278. [CrossRef]

46. Kaur, L.; Singh, J. Starch: Modified starches. In Encyclopedia of Food and Health; Academic Press: Oxford, UK, 2016; pp. 152-159. [CrossRef]

47. Zajac, A.; Hanuza, J.; Wandas, M.; Dyminska, L. Determination of $N$-acetylation degree in chitosan using Raman spectroscopy. Spectrochim. Acta Part A 2015, 134, 114-120. [CrossRef] [PubMed] 
48. Almeida, A.R.; Alves, R.S.; Nasciembem, M.R.L.; Stephani, R.; Poppi, R. Determination of amylose content in starch using Raman spectroscopy and multivariate calibration analysis. Anal. Bioanal. Chem. 2010, 397, 2693-2701. [CrossRef] [PubMed]

49. Zhang, K.; Peschel, D.; Helm, J.; Groth, T.; Fischer, S. FT Raman investigation of novel chitosan sulfates exhibiting osteogenic capacity. Carbohydr. Polym. 2011, 83, 60-65. [CrossRef]

50. Ulahannan, R.T.; Panicker, C.Y.; Varghese, H.T.; Musiol, R.; Jampilek, J.; Van Alsenoy, C.; War, J.A.; Srivastava, S.K. Molecular structure, FT-IR, FT-Raman, NBO, HOMO and LUMO, MEP, NLO and molecular docking study of 2-[(E)-2-(2-bromophenyl)ethenyl]quinoline-6-carboxylic acid. Spectrochim. Acta Part A Mol. Biomol. Spectrosc. 2015, 151, 184-197. [CrossRef] [PubMed]

51. Hong, Y.; Liu, G.; Gu, Z. Recent advances of starch-based excipients used in extended-release tablets: A review. Drug Deliv. 2016, 23, 12-20. [CrossRef] [PubMed]

52. Ninthya, A.; Chandra Mohan, S.; Jeganathan, K.; Jothivenkatachalam, K. A potential photocatalytic, antimicrobial and anticancer activity of chitosan-copper nanocomposite. Int. J. Biol. Macromol. 2017, 104, 1774-1782. [CrossRef]

53. Alsaggaf, M.S.; Moussa, S.H.; Elguindy, N.M.; Tayel, A.A. Fungal chitosan and Lycium barbarum extract as anti-Listeria and quality preservatives in minced catfish. Int. J. Biol. Macromol. 2017, 104, 854-861. [CrossRef] [PubMed]

(C) 2017 by the authors. Licensee MDPI, Basel, Switzerland. This article is an open access article distributed under the terms and conditions of the Creative Commons Attribution (CC BY) license (http:/ / creativecommons.org/licenses/by/4.0/). 